\title{
“Isto não é uma taberna, é um casino!": o curso de pagador de banca
}

\author{
JOÃO GOMES
}

UNIVERSIDADE DE LISBOA E FUNDAÇÃO PARA A CIÊNCIA E TECNOLOGLA, LISBOA, PORTUGAL HTTPS://ORCID.ORG/0000-0002-3954-I977

\section{Introdução}

Durante longas décadas, os casinos em Portugal permaneceram universos sociais e laborais hermeticamente fechados. Moralmente condenado e juridicamente proibido desde as Ordenações Afonsinas, no século XV, o jogo proliferava por todo o território nacional, pelo menos, desde o século XIX (Vaquinhas 2006; Crespo 1981; 2012). Em virtude da ineficácia da sua proibição generalizada, o Estado decide regulamentar o jogo em 1927, já no contexto da Ditadura Militar (Vaquinhas 2006; Deus e Lé 2016; 2017). Mas a regulamentação do jogo não foi sinónimo de liberalização (Gomes no prelo). Pelo contrário, a regulamentação visava isolar a actividade em determinadas “zonas de jogo" legalmente definidas pelo Estado e garantir o monopólio da sua exploração (Decreto-lei nº 14643 de 3 de Dezembro). Este documento estabelecia duas “zonas de jogo permanentes": Estoril e Funchal; e seis "zonas de jogo temporárias" (abertas de 1 Junho a 31 de Outubro): Santa Luzia (transferida, posteriormente, para a Póvoa do Varzim), Espinho, Cúria, Figueira da Foz, Sintra e Portimão (Ibidem ${ }^{1}$. Mimetizando o isolamento em "guetos de riqueza" (Lefebvre 2011:98) a que a indústria do jogo havia sido votada, os trabalhadores dos casinos rapidamente se apropriaram deste contexto, manipulando-o em seu próprio benefício. $\mathrm{O}$ isolamento e o reduzido mercado de trabalho, aperceberam-se, poderiam ser utilizados como armas, permitindo assegurar privilégios profissionais através de práticas de “oclusão social” (Weber 1968; Parkin 1979) que visavam restringir o acesso à categoria profissional de pagador de banca (dealer/croupier), preservar a raridade do seu título (Bourdieu 2018) e impedir a vulgarização do “segredo da arte” (Mónica 1986:91).

1 Apesar das inúmeras alterações legislativas desde 1927, o modelo das "zonas de jogo" e da concessão em regime de monopólio sobrevive ainda hoje (Roque 2011). 
Este entrincheiramento profissional permitia, aos trabalhadores, construírem "uma muralha à sua volta, tentando proteger-se, de mil e uma maneiras, da invasão de estranhos" (Patriarca 1994:813). Ao regime corporativo do Estado Novo, o Sindicato Nacional (SN) do jogo respondia com políticas de closed shop (Gomes no prelo). Inclusivamente, o primeiro regulamento da escola profissional de pagadores de banca apenas foi oficializado em 1956, 29 anos depois da regulamentação do jogo em Portugal (Ibidem). Mesmo neste caso, o SN não aceitara, voluntariamente, este desfecho. Pelo contrário, foi a isso obrigado pela Direcção-Geral do Trabalho e das Corporações, dado que as suas sistemáticas práticas de "oclusão social" haviam resultado numa generalizada "falta de profissionais" (ANTT, SAS/003/003/00139:s/p). Durante todo o período do regime corporativo, observamos a mesma dinâmica: as empresas concessionárias propõem novos recrutas e o $\mathrm{SN}$, dispondo dos instrumentos corporativos da sindicalização obrigatória e da concessão da carteira profissional (Patriarca 1994), rejeita a sua inclusão (Gomes no prelo). Ainda hoje, o Sindicato dos Profissionais de Banca nos Casinos define-se como um organismo corporativo, embora já sem a capacidade de impor a anterior dinâmica de closed shop. No entanto, o acesso ao universo laboral dos casinos permanece selectivo, dado que depende, em grande medida, de relações clientelistas (Ibidem).

Ao contrário do que sucede, por exemplo, em Las Vegas, onde as escolas de dealers funcionam ininterruptamente (Sallaz 2009), em Portugal, os cursos são organizados pelo Turismo de Portugal a pedido das empresas concessionárias. Os cursos têm a duração de 3/4 meses e são compostos por 5 módulos: "técnicas de atendimento"; "turismo"; "higiene e segurança no trabalho"; "legislação"; e "serviço em banca de casino". No final do curso, os alunos são submetidos a duas provas: uma teórica, que procura avaliar o conhecimento dos formandos sobre a legislação do jogo; e uma prática, que pretende apreciar as competências dos candidatos nos jogos da roleta americana, blackjack e banca francesa ${ }^{2}$. O curso não implica a contratação definitiva dos candidatos, apenas o ensino das competências profissionais de pagador de banca e a certificação que habilita ao exercício da profissão.

Este é o primeiro artigo que propõe analisar, etnograficamente, as dinâmicas de constituição do "habitus" (Bourdieu 2010) profissional dos pagadores de banca em Portugal ${ }^{3}$. Em primeiro lugar, pretende-se examinar os métodos de inculcação e incorporação das técnicas e atitudes correctas. Em detrimento de uma rígida separação entre corpo e mente, que tende a objectificá-los, procura-se analisar "os processos de incorporação das maneiras de pensar e de agir” (Monteiro 2014:12). Em segundo lugar, este artigo procura averiguar os processos de apropriação destas competências, simultaneamente, subjectivos e objectivos, mentais e físicos, materiais e simbólicos. Esta "elaboração pessoal de um habitus social" (Elias 1994:141), este "ajustamento inconsciente das posições e das atitudes" (Bourdieu 2018:95), esta transformação da "história reificada" em "história incorporada" (Ibidem), esta conversão das "estruturas sociais" em "estruturas disposicionais" (Idem 2010) e, por fim, este processo de adequação entre "habitus primários" (familiares) e "habitus secundários" (escolares) (Idem 1992) fazem da "necessidade", "virtude" (Idem 2010) e evocam "[...] todo o processo de investimento que leva os trabalhadores a contribuírem para a sua própria exploração pelo próprio esforço que fazem para se apropriarem do seu trabalho e das suas condições de trabalho e que os faz apegarem-se ao seu ofício" (Idem 2018:95). As "técnicas do corpo"

2 Por questôes de espaço, este artigo debruça-se, exclusivamente, sobre o jogo da roleta americana.

3 Os casinos e os interlocutores mencionados neste artigo estão protegidos pelo anonimato. Todos os nomes presentes neste texto são fictícios. 
(Mauss 2003) e da mente inculcadas, incorporadas e apropriadas introduzem o agente a todo um universo social e laboral, material e simbólico que é, igualmente, o processo de constituição de todo um saber ser e saber estar. Para analisar estes processos, entre Outubro de 2018 e Março de 2019, utilizando a técnica da observação participante, frequentei o curso de pagador de banca de casino.

\section{O cálculo, "a skill mais importante”}

No início de Outubro de 2018, submeti a minha candidatura ao curso de pagador de banca de casino. Realizados os testes de selecção, um de "cultura geral” e outro de "cálculo mental", seguiu-se a convocação de entrevistas presenciais. Na pequena sala de entrevistas da Escola Superior de Hotelaria e Turismo da localidade, um dos Directores de Jogo do casino, de semblante carregado e austero, perscrutava-me de alto a baixo. Segundos depois, debruçou-se sobre a mesa e questionou: "o que é que se passou no teste de cálculo? Você chumbou! Já não devia estar nesta fase”. Perplexo com a objectividade sem rodeios do Director, desculpei-me com a falta de prática a matemática. Incrédulo, o Director de Jogo insistiu: "a sua nota deixa-me preocupado, porque vocêfalhou naquela que é a skill mais importante no trabalho de um pagador de banca".

Apesar da reprimenda, fui seleccionado para o curso de pagador. No entanto, previa enormes dificuldades, dada a minha comprovada incompetência na tarefa do cálculo. Para minha surpresa, decorridas duas semanas de formação, eu era já um dos melhores alunos nos exercícios de cálculo. Não era, de todo, o mais rápido, mas era um dos mais precisos. Quando, na quarta semana de formação, realizámos uma bateria de testes para averiguar o nosso progresso, eu sentia-me já perfeitamente à vontade neste particular. Sentado numa banca de baccarat, realizava um conjunto de exercícios através de uma aplicação no tablet de um dos formadores. O Director de Jogo que me havia entrevistado, aproximou-se, mas eu não me apercebi, dado que estava concentrado nos exercícios. A determinada altura, o Director interrompeu-me: "isso está bem melhor". Olhei para trás, surpreendido, e respondi: "é a prática”. Mas não era só a prática. Isto porque os formandos, no curso de pagador, não exercitam propriamente o cálculo. O que aprendemos, na verdade, são truques e atalhos que nos permitem chegar ao resultado sem utilizar, ou reduzir ao máximo, o cálculo. Efectivamente, aquilo que desenvolvemos no curso de pagador é, em primeiro lugar, a memória visual.

Especificamente para os pagamentos na roleta americana, os candidatos devem aprender aquilo a que os formadores chamam de picture bets. Picture bets são apostas, feitas pelos clientes, cujo resultado os pagadores devem conhecer pela mera visualização das fichas no pano. Mas comecemos pelo princípio. A roleta tem 37 números (do 0 ao 36$)^{4}$ e é um jogo que permite uma enorme diversidade de apostas e resultados. O pleno ou straight up (a aposta num único número) paga 35x o valor da aposta, o cavalo ou split (aposta em dois números) 17x, a rua ou street (aposta em 3 números) 11x, o quadro ou corner (aposta em 4 números) 8x e a linha ou line (aposta em 6 números) 5x. Existem ainda as casas exteriores que pagam o mesmo valor da aposta - as cores (encarnado ou preto), o par-impar e o baixo-alto (1-18 ou 19-36) - e as casas exteriores que pagam $2 \mathrm{x}$ o valor apostado - as dúzias (1-12, 13-24, 25-36) e as colunas. Para complicar a tarefa do cálculo, nas casas interiores, podem apostar sete jogadores em simultâneo, não existindo um número máximo de jogadores nas casas exteriores. Além disso, o cliente, dependendo do casino, pode jo-

4 Em Las Vegas, existem roletas com dois zeros, representadas no exemplo da figura 1. 
gar com fichas de $1 €, 2,5 €, 5 €, 10 €, 25 €$ ou $50 €$. Os jogadores têm ainda a possibilidade de apostar várias fichas nas mesmas casas de aposta, por exemplo, duas fichas no pleno, quatro no cavalo, duas no quadro, cinco na rua, dez na linha, etc.

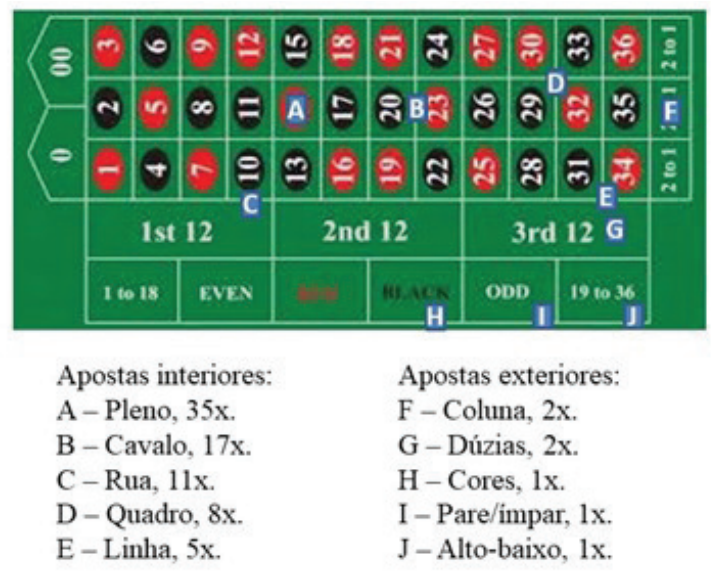

Figura 1. Possibilidades de aposta na roleta. Fonte: www.google.pt.

Assim, as picture bets são uma determinada exposição das fichas no pano que o aspirante a pagador deverá estudar afincadamente. Conhecer instintivamente as picture bets e os resultados que lhes correspondem permite reduzir, substancialmente, esta enorme imprevisibilidade de resultados. Desta forma, se o jogador apostar duas fichas no quadro $(2 \times 8=16)$ e uma no pleno $(1 \times 35=35)$, o pagador deverá saber imediatamente e sem cálculo que o resultado é 51 unidades, porque esta aposta corresponde à picture bet do mickey mouse. Se, por outro lado, a aposta vencedora corresponder a um pleno $(1 \times 35=35)$ e quatro cavalos $(4 \mathrm{x}$ $17=68$ ), o pagador deverá saber, rapidamente, que o prémio ganho corresponde a 103 unidades, porque esta é a picture bet do dinner for four. Existe uma enorme diversidade de picture bets, quase todas, individualmente denominadas. Olhando para as fichas dispostas no pano, já não estamos a calcular, mas a reconhecer um padrão, um nome e um número. O cálculo nunca é completamente erradicado, mas reduzido a somas e subtracções básicas. Vejamos, por exemplo, a picture bet representada à direita e na linha inferior da figura 2. O resultado, como assinalado na legenda, é 59 unidades: um pleno (ou, 1 × $35=35$ ) + três quadros (ou, 3 x 8 =24). O pagador, no entanto, não faz estes cálculos individuais. Ao invés, ele chega, imediatamente, às 51 unidades, porque o pleno e os dois quadros da linha superior correspondem à picture bet do mickey mouse. Desta forma, o pagador apenas acrescenta o quadro da linha inferior, ou seja, apenas soma oito aos 51.

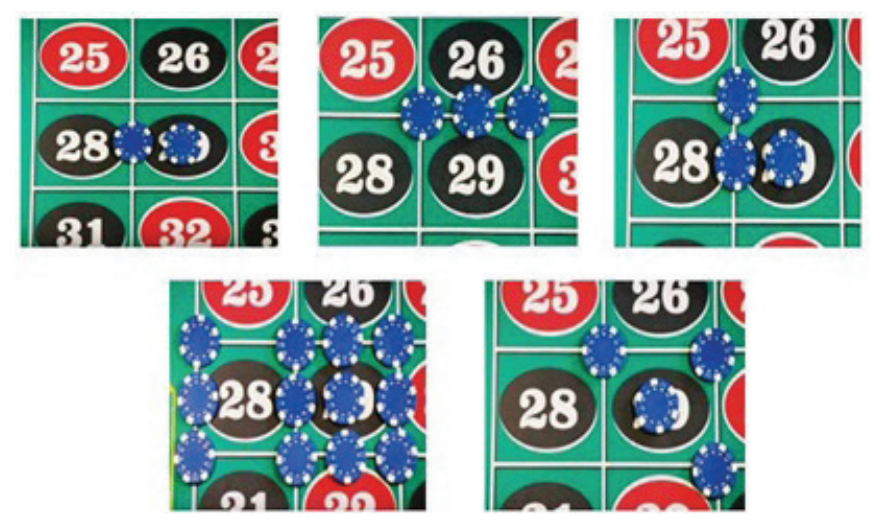

Figura 2. Exemplos de picture bets. Os resultados são, por ordem da esquerda para a direita e de cima para baixo: 52 (dinner for one), 33 (christ), 60 (gun), 156 (completo dos números centrais), 59 (mickey mouse mais um quadro). Fonte: www.youtube.com. 
Para além das picture bets, existem muitos outros atalhos que simplificam o trabalho dos pagadores de banca na roleta. O próprio layout do pano pode auxiliar o pagador a chegar aos resultados das apostas, como podemos observar na figura 3.

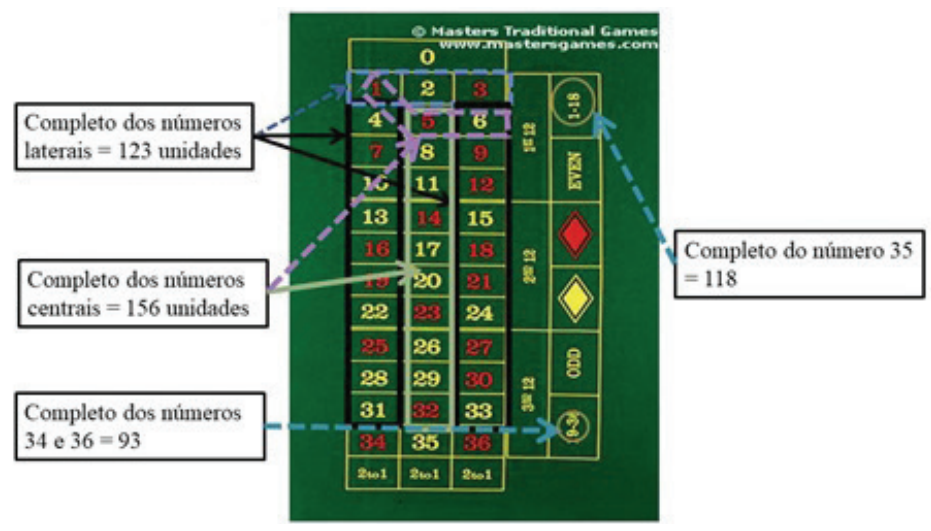

Figura 3. Atalhos no layout da roleta. Fonte: www.google.pt.

A tarefa complica-se quando pretendemos calcular o valor do prémio do cliente e não meramente o número de fichas ganhas. Isto porque o cliente, tal como assinalado anteriormente, pode jogar com fichas de $1 €, 2,5 €, 5 €, 10 €, 25 €$ ou $50 €$. No entanto, também neste caso existem truques que nos permitem reduzir o cálculo ao máximo. Vejamos o exemplo mais comum, as apostas com fichas de $5 €$. Neste caso, bastará dividir por 2 o número de fichas ganhas, acrescentando, de seguida, uma casa decimal. No exemplo da picture bet do mickey mouse, o jogador premiado com 51 unidades, ganhou $255 €$, porque $51: 2=25,5$. Porém, este atalho era desaconselhado pelos formadores, porque não dispensava, suficientemente, a utilização do cálculo. Mais uma vez, eles insistiam no desenvolvimento da memória visual. Como referia um dos formadores:

Se usarem a matemática, mais tarde ou mais cedo, vão enganar-se. Um dia que estejam cansados, às quatro da manhã numa banca, vão bloquear e depois não se conseguem desenrascar. Utilizem os truques que vos ensinamos, se os souberem de cor nunca se enganam.

Desta forma, para calcular, em dinheiro, os prémios dos jogadores, devemos imaginar a exposição dos pagamentos no pano. Como qualquer outro procedimento na roleta americana, os pagamentos são expostos de acordo com um método específico. Imaginemos, novamente, a picture bet do mickey mouse. $\mathrm{O}$ resultado, como observámos, é 51 unidades. Por sua vez, os conjuntos unitários de fichas que os pagadores podem manipular são os seguintes: 20 fichas (ou stack); cinco fichas reunidas num único monte; e uma, duas, três ou quatro fichas deitadas sobre o pano.

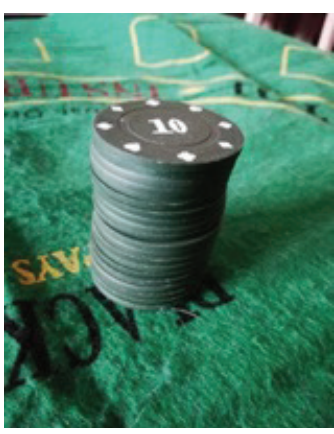

Figura 4. Stack de fichas. Fonte: autor. 
Assim, para pagar 51 unidades, o pagador expõe de imediato duas stacks, ou seja, 40 fichas, colocando-as lado a lado sobre o pano. Ficam a faltar, portanto, 11 fichas para completar o pagamento. Como tal, o pagador expõe, de seguida, dois montes de cinco unidades (10 fichas) e uma ficha isolada (ver figura 5).

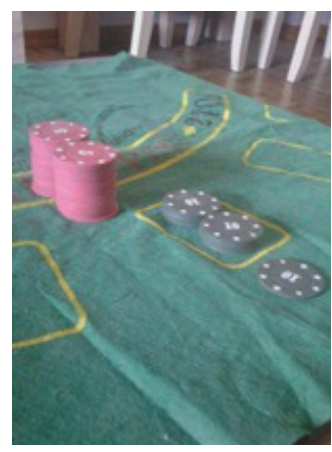

Figura 5. Exposição do pagamento de 51 unidades. Fonte: autor.

Este método é utilizado para quase todos os pagamentos. Se o jogador for premiado com 60 unidades, o pagador expõe, simplesmente, três stacks sobre o pano $(20+20+20=60)$. Se o jogador ganhar 74 unidades, o pagador expõe os mesmos três stacks (60 unidades), dois montes de cinco fichas (10 unidades) e quatro unidades deitadas sobre o pano. Mas como calcular o valor monetário dos prémios a partir da exposição dos pagamentos? Os pagadores de banca devem conhecer, instintivamente, o valor monetário dos conjuntos unitários de fichas. Se o cliente estiver a jogar com fichas de $5 €$, o pagador deverá saber, sem cálculo, que uma stack representa $100 €$. Da mesma forma, o pagador saberá que um monte de cinco fichas representa $25 €$. Assim, imaginando as fichas expostas para pagamento no pano, que cumprem sempre o mesmo método, o cálculo é reduzido substancialmente. No exemplo da picture bet do mickey mouse, o pagador imagina, imediatamente, a exposição das fichas no pano: duas stacks $(100+100=200)$, dois montes de cinco fichas $(25+25=50)$ e uma ficha isolada $(5)$. O jogador ganhou $255 €$. O cálculo, não desaparecendo totalmente, é reduzido a somas básicas.

Este método de cálculo assinala uma importante característica do trabalho dos pagadores de banca. Se conhecemos, instintivamente, os valores das stacks e dos montes de cinco fichas, já não estamos a calcular, mas a traduzir. Mais especificamente, estamos a traduzir o valor unitário em valor monetário. Aliás, um dos formadores costumava assinalar que as unidades eram a "linguagem nativa" ou "primária" dos pagadores de banca. O pagador trabalha sempre em unidades, pensa sempre em unidades e calcula sempre em unidades. Quando pretende saber o valor monetário, o pagador imagina a exposição dessas unidades no pano e traduz o valor unitário em valor monetário. A preponderância da tradução supera de tal forma a tarefa do cálculo que, inicialmente, tal como acontece quando somos introduzidos a dois idiomas em simultâneo, confundimos e misturamos os dois códigos linguísticos. Acontece com bastante frequência, por exemplo, que um formando conte duas fichas no valor de $5 €$, como $2 €$ e não como duas unidades que valem $10 €$. Ou, inversamente, conte duas fichas no valor de $5 €$, como 10 unidades e não duas unidades que equivalem a $10 €$. Ou seja, isto não são erros de cálculo, mas de tradução. O trabalho dos pagadores depende, portanto, de duas competências fundamentais: memória visual e tradução. No entanto, só a prática e o treino permitem adquirir a celeridade, a precisão e a destreza necessárias. Mas se o cálculo não representa, afinal de contas, "a skill mais importante no trabalho de um pagador", quais são as competências que assumem maior preponderância? 


\section{Os taberneiros}

Na pequena sala de formação, os alunos distribuíam-se, uniformemente, pelas três bancas de roleta americana. Seguindo as indicações dos formadores, todos eles antigos pagadores de banca, executavam um exercício simples: o chipping. Este procedimento, que permite o aquecimento das mãos, pulsos e dedos, consiste em recolher, individualmente, as fichas deitadas e dispersas pelo pano até refazer a stack original. Porém, a recolha das fichas não é destituída de método. O objectivo é pressionar, com o polegar, uma das extremidades da ficha e, com o indicador, recolhê-la a partir da extremidade oposta. Esta ficha deve ser preservada junto à palma da mão, enquanto recolhemos as restantes unidades. Este processo deve ser realizado com as duas mãos em simultâneo. Ao fim de algumas semanas, o formando deverá conseguir refazer cinco stacks (100 fichas) em menos de 30 segundos. Somos sempre aconselhados a não contar as fichas para refazer as stacks. O objectivo é que o candidato sinta, manualmente, que está a segurar 20 fichas.

Posteriormente, aprendemos outras técnicas e movimentos básicos: o corte (cutting) e o encosto (sizing). Estes exercícios são repetida e intensivamente treinados durante o curso de forma a inculcar, nos formandos, o correcto manuseamento das fichas. Só com o tempo, os alunos ganham a celeridade e a precisão técnica exigidas. Aliás, o grau de excelência apenas é alcançado depois de vários anos de experiência profissional. Isto porque a técnica depende de movimentos pouco naturais, de uma coordenação motora precisa e de posturas minuciosamente treinadas. As posições dos dedos, mãos, pulsos, braços, torço, ombros e pernas são fundamentais para o sucesso destas diferentes tarefas. A primeira dificuldade apresenta-se, desde logo, em segurar e manusear uma stack na mão, sem que as fichas caiam no pano. Todos os dedos têm um posicionamento específico, mas o mais importante é o mindinho. Enquanto os outros dedos caem verticalmente sobre a stack, rodeando-a, o mindinho deve posicionar-se bem atrás, contrabalançando todos os movimentos da stack na mão. Ele nada segura, mas a sua colocação estratégica permite realizar todos os movimentos necessários. Paulatinamente, uma dor tímida, mas persistente começou a invadir as mãos, os pulsos e os dedos dos alunos. No entanto, um dos formadores, corrigindo, pormenorizadamente, os procedimentos dos candidatos, assegurava: "é suposto doer. Se não dói, não estão a fazer bem".

A técnica do corte, por sua vez, consiste em retirar um determinado número de fichas de uma stack. Mais uma vez, existe um método e uma técnica correctas. Por exemplo, nunca se retira, num único movimento de corte, seis fichas de uma stack. Podemos cortar uma, duas, três, quatro ou cinco fichas num único movimento de corte, mas nunca um número superior. Por exemplo, se pretendemos retirar 11 fichas de uma stack, o procedimento é o seguinte: corte de cinco fichas + corte de cinco fichas + corte de uma ficha. A performance correcta deste procedimento é, mais uma vez, altamente dependente do posicionamento do mindinho. Em primeiro lugar, devemos segurar uma stack numa única mão. $\mathrm{O}$ mindinho deve contrabalançar os movimentos da mão e dos restantes dedos, mas é o indicador que deve efectuar o corte. Este deve deslizar suavemente pela stack num movimento vertical e ascendente. Quando o indicador alcança o número de fichas que pretendemos separar da restante stack, efectuamos o corte. Não devemos contar as fichas à medida que deslizamos o indicador pela stack. Mais uma vez, o objectivo é sentir, manualmente, o número de fichas que estamos a cortar para que o movimento pareça o mais natural, fluido e instintivo possível. Ao realizar o corte, o indicador deve pressionar, para trás, as fichas imediatamente acima das pretendidas. Ao empurrar as fichas, o mindinho suporta-as, impedindo-as de caírem no pano. Por sua vez, 
o indicador, ao efectuar o corte e ao empurrar as fichas contra a mindinho, deve fazer um arco invertido e nunca o que os formadores designam por gancho, isto é, um arco interior.

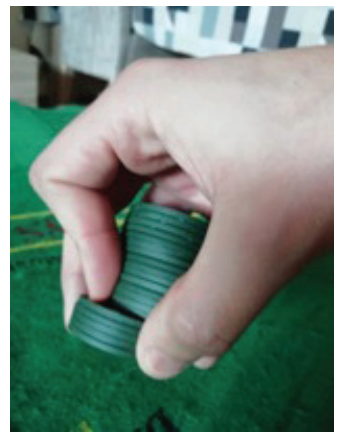

Figura 6. A técnica do corte. Fonte: autor.

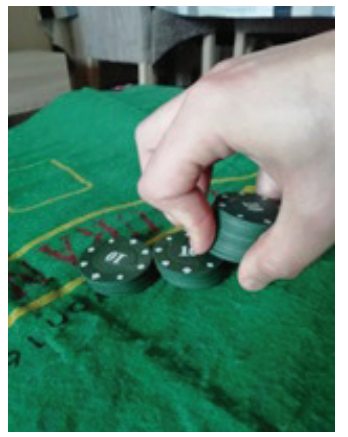

Figura 7. A técnica do encosto. Fonte: autor.

O encosto, por sua vez, deriva do primeiro movimento de corte executado, mas apenas realizamos este procedimento se o objectivo for retirar conjuntos de fichas em múltiplos de cinco (ou de quatro, no caso das fichas de 2,5€ ou 25€). Por exemplo, se pretendemos retirar 15 fichas de uma stack, o método correcto é o seguinte: cortamos as primeiras cinco fichas; pousamos a restante stack no pano e deslizamo-la suavemente até esse primeiro monte; de seguida, utilizamo-lo como unidade de medida, ou seja, o indicador, em vez de cortar directamente da stack, desliza pela superfície da ficha que coroa o primeiro monte de cinco unidades e, nesse movimento, empurra as fichas da restante stack para trás, contra o mindinho. Repete-se o mesmo procedimento de forma a deixar, no pano, 15 fichas em três montes de cinco unidades.

Para além destes movimentos, aprendemos também a empurrar (puxing) as fichas para o cliente. Mais uma vez, o sucesso desta tarefa depende do correcto posicionamento dos dedos. De outra forma, as stacks tombam, inevitavelmente, sobre o pano. Basta um dedo mal posicionado, um movimento demasiado brusco, uma hesitação nos gestos, uma ligeira convulsão na mão e os prémios dos jogadores caem desajeitadamente sobre a banca. Mas a colocação dos dedos varia consoante a dimensão dos prémios. Mais concretamente, varia de acordo com a quantidade de stacks que os compõem. A técnica correcta para empurrar duas stacks (40 fichas) é diferente da que é exigida para empurrar um bloco (cinco stacks, ou 100 fichas).

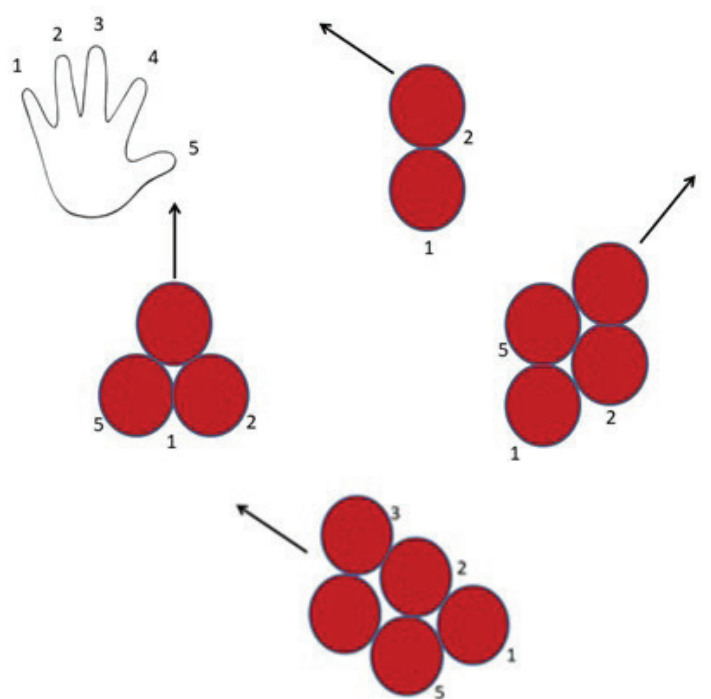

Figura 8. A correcta posição dos dedos consoante o número de stacks a empurrar. Fonte: Manual do Croupier. 
Apesar da diversidade de técnicas e procedimentos, o princípio é sempre o mesmo: os gestos, os movimentos e as técnicas devem ser executados de forma precisa, natural e fluida. O objectivo do curso é transformar em atribuida, uma técnica arduamente adquirida, tornar natural, uma técnica que implica esforço e treino intensivos. As fichas devem fazer parte da nossa mão e a técnica deve ser uma segunda natureza que performatizamos instintivamente. A "violência simbólica" e material da inculcação e incorporação deste "arbitrário cultural” (Bourdieu 1992), desta "técnica do corpo" (Mauss 2003) específica, permanece encoberta pelo estado acabado em que a encontramos no casino. Por outro lado, o ajustamento entre "posição" e "atitude", a dialéctica da apropriação entre posto e agente também dissimula a violência que está na sua origem (Bourdieu 2018). Os alunos, com o tempo, incorporando o "arbitrário cultural" que a formação pretende inculcar, começam a desenvolver uma técnica específica e individual. Tendo sido apropriados pelo posto, pela técnica que lhes constrange os movimentos, que lhes disciplina os gestos, que lhes "dociliza" os corpos (Foucault 1999), que lhes "inscreve" no corpo (Clastres 2003) e na mente esse saber específico, os indivíduos começam a apropriar-se desse posto, dessa técnica e desse saber. É uma "elaboração pessoal de um habitus social" (Elias 1994:141). Na sua investigação sobre a cultura de trabalho dos dealers em Las Vegas, H. Lee Barnes (2002:3,104) assinalava: "each dealer has his own signature. In that neatly fanned-out deck is an expression of who that dealer is. It is subtle [...]. Years go into honing finger dexterity to the degree that hand and mind coordinate complex moves seemingly without willful effort". A dor, com o tempo, desvanesce-se. Os movimentos, gestos e procedimentos que antes levavam longos minutos e que exigiam uma enorme concentração, parecem agora operar-se através dos corpos dos alunos, automática e instintivamente. $\mathrm{O}$ corpo parece agora o meio domesticado através do qual a técnica se exprime. Mas esta é, naturalmente, uma forma equívoca de apreender o fenómeno, dado que o corpo, domesticado pela técnica inculcada, é também o corpo que se apropria dessa técnica e que a performatiza. Assim, os processos simultâneos de inculcação e de apropriação produzem o "ajustamento" entre posto e agente e transformam a "história reificada" em "história incorporada" (Bourdieu 2018). A "necessidade" torna-se "virtude" (Idem 2010) a partir do momento em que o agente se investe no posto, moldando-o e sendo moldado por ele.

Inicialmente, quando começámos a aprender os procedimentos de trabalho na roleta americana, fiquei surpreendido com o grau de constrangimento a que os corpos dos pagadores se sujeitavam. De tal forma que começava a dar razão ao gracejo de um dos formadores: "isto só custa os primeiros 40 anos". Na roleta, o pagador deve manter-se encostado ao estrado da banca, movendo-se lateralmente. As pernas devem estar ligeiramente afastadas, as costas direitas e a cabeça inclinada sobre o pano. As mãos devem estar sempre abertas e visíveis em cima da banca. Recebendo fichas dos clientes, o pagador deve manuseá-las com a mão de fora, mas quando lança a bola ou compõe os prémios dos jogadores, deve manipular os instrumentos de trabalho com a mão de dentro ${ }^{5}$. Antes de tocar em fichas ou dinheiro, deve sempre limpar as mãos. Este último procedimento consiste em passar uma mão sobre a outra, demonstrando, às câmaras de vigilância, aos superiores hierárquicos e aos jogadores, que o pagador não subtraiu nem adicionou qualquer valor monetário ao prémio ou aposta do jogador. Este procedimento é de tal forma inculcado que dei por mim a limpar as mãos fora do contexto do curso: a pagar o café, co-

5 Na roleta, a mão de fora é a mão que se encontra mais distante do prato giratório. A mão de dentro é a que dele mais se aproxima. 
locava as moedas em cima do balcão e limpava as mãos; no supermercado, retirava produto da prateleira, colocava-a no carrinho das compras e limpava as mãos; chegava a casa, pendurava o casaco e limpava as mãos. No entanto, apesar desta rígida e minuciosa formação, os alunos vão-se apropriando do posto. Ao fim de algumas semanas de treino, comecei, como outros colegas meus, a sentir um certo orgulho em relação à minha técnica e à minha forma de pagar, elogiada pelos formadores. Num determinado dia de formação, regressando de uma pausa de 15 minutos, entrei na sala antes dos meus colegas. Um dos formadores estava sentado numa cadeira, enquanto conversava descontraidamente com um dos seus pares. Como não estava mais ninguém na sala, resolvi praticar os exercícios do corte e do encosto. Ao fim de alguns segundos, o formador interrompeu-me: "João, estás a ir bem, consegues fazer isso com a esquerda?". Repeti os exercícios com a mão esquerda. Finalizada a tarefa, ele afirmou: “Ok, com a direita está muito bem, a esquerda precisa de prática”. O elogio repetiu-se alguns dias depois, quando o formador anunciou: "tens um belo toque". Estes dois relatos não procuram evidenciar a minha qualidade numa banca, mas ilustrar o processo pelo qual os formandos se tornam investidos no curso. Este processo era comum à grande maioria dos alunos, à medida que iam ganhando um certo orgulho relativamente à sua técnica. Desta forma, os agentes apropriavam-se do seu posto pela elaboração pessoal de um habitus social. O domínio de uma técnica específica, escassa no mercado de trabalho nacional, garantia o investimento dos alunos no curso e funcionava como recurso que eles mobilizavam para se constituírem, simbolicamente, como "agentes não subordinados" (Sherman 2007; Lamont 2000). Mas que técnica era esta? O que significava, na verdade, este "belo toque"? Como referido anteriormente, o "belo toque" remete para a fluidez e naturalidade da performance. Mas, mais concretamente, o "belo toque" é a elegância, a graciosidade e a suavidade dos movimentos e gestos corporais. Inclusivamente, os formadores costumavam insistir: "não façam as coisas com pressa, façam com calma, a rapidez vem com o tempo, o importante, para já, é fazer bem”; "não façam tanto barulho a mexer nas fichas, isto é um casino"; "sintam as fichas, não as contem"; "não sejam brutos, as fichas são vossas amigas". Portanto, o "fazer bem", isto é, a técnica correcta é a elegância, graciosidade, suavidade, fluidez e naturalidade da performance. Como assinalava H. Lee Barnes (2002:2): "the dealers hand movements are in themselves the real art, a ballet of motion, the paying of cards or cutting of chips or sweeping of a layout - all art, all invisible”. A este respeito, Jeffrey Sallaz (2009:3), na sua investigação etnográfica sobre os dealers em Las Vegas e Joanesburgo, referia: "dealing remains a craft”.

Mas a inculcação, incorporação e apropriação desta técnica não se realiza sempre da mesma maneira, ao mesmo ritmo e com o mesmo grau de sucesso. O carácter selectivo deste processo manifesta-se, mais nitidamente, junto daqueles que apresentam maiores dificuldades de aprendizagem. Estas dificuldades, no entanto, não representam diferenças qualitativas universais ou diferentes níveis de inteligência. Ao invés, representam um desajuste entre "habitus primários" e "habitus secundários" (Bourdieu 1992). A eficácia de qualquer "acção pedagógica" é função da distância entre "habitus primários" e "habitus secundários" (Ibidem). "O corpo que mediatiza a aquisição de um saber", que serve de "ponto de encontro" entre o indivíduo e o "ethos tribal” (Clastres 2003:198) não é uma tábua rasa. É um corpo já dotado de "habitus primários", isto é, familiares (Bourdieu 1992). O se exige dos formandos no curso de pagador é, portanto, a inculcação, incorporação e apropriação de um "habitus secundário", que será tanto mais efi- 
caz quanto mais próximo estiver dos "habitus primários" dos alunos, ou seja, quanto mais os formandos possuírem, em si, o código que lhes permita decifrar a mensagem transmitida (Ibidem). A distância entre "habitus primários" e "habitus secundários", distância que complica a dialéctica de apropriação entre posto e agente manifesta-se, frequentemente, em momentos de avaliação, quando os formandos se encontram sob intensa observação. Nestas alturas, as mãos de alguns formandos (eu incluído) começavam a tremer incontrolavelmente. Por vezes, os formadores solicitavam aos alunos a repetição dos exercícios, enquanto filmavam com a câmara do telemóvel. Automaticamente, os gestos, ainda agora fluidos, tornavam-se hesitantes e espasmódicos. "Liga-se a câmara e vocês desmontam-se todos", gracejava um dos formadores. A elegância, a suavidade, a naturalidade e a fuidez dos movimentos e gestos corporais dependem, em grande medida, de um auto-controlo e de uma auto-disciplina, simultaneamente, corporais e emocionais. A mente e o corpo nunca se separam. Qualquer hesitação ou tremor, por mais breves que sejam, prejudicam a performance técnica, baseada numa minúcia de disposições corporais. O suor, que se imiscui pelos dedos em momentos de tensão, introduz fricção nos movimentos e prende às mãos dos alunos, as fichas e os restantes instrumentos de trabalho. As fichas, empurradas pelo pano, caem com o tremor das mãos e o mau posicionamento dos dedos. As bolas na roleta, presas às mãos dos alunos pelo suor, são lançadas para fora do prato, embatendo com estrondo nas paredes. Não tremer atrás de uma banca de jogo, não hesitar nos procedimentos de trabalho, realizar os movimentos com fluidez, naturalidade e elegância, são as marcas do ajustamento e da apropriação, isto é, são os sinais da pertença e da identificação sócio-profissional. Assim, este “capital físico" (Shilling 2003; Wolkowitz 2006), assente na elegância, graciosidade, fluidez, naturalidade e confiança de gestos e movimentos corporais, detendo o seu respectivo valor no "campo social" em que se apresenta (isto é, nos casinos), é parte integrante de todo um "habitus" (Bourdieu 2010) e de todo um saber ser e saber estar. A performance da elegância corporal implica a performance da elegância emocional e uma determinada relação com o corpo implica uma determinada relação com o mundo. Os diferentes graus de sucesso do ajustamento entre posto e agente, expressando a distância entre "habitus primários" e "secundários", não reflectem meramente a hierarquia entre os formandos no curso de pagador, sinalizam, igualmente, a existência de assimetrias sociais mais amplas, porque as "estruturas disposicionais" evidenciam "estruturas sociais" (Idem 1992). O processo de apropriação e ajustamento pode resultar numa síntese entre "habitus primários" e "secundários", mas nunca na eliminação de um dos dois (Ibidem).

Dada a importância da elegância, graciosidade, suavidade e confiança na performance da técnica correcta, não surpreende que o melhor aluno do curso, aquele que se destacava, de longe, de todos os outros, tivesse praticado, desde tenra idade, danças de salão. Apesar da evidente discrepância entre estes "campos sociais", existe uma certa homologia estrutural, ou "afinidade" (Idem 2018:253), entre a técnica e, por consequência, os "habitus" que, num e noutro caso, são inculcados, incorporados e apropriados. Esta homologia estrutural dissimulada entre diferentes "campos", que favorece "o parentesco das visões do mundo" (Ibidem), transforma o ajustamento entre posto e agente, consequência de assimetrias sociais e de condições de vida desiguais, em talento inato e habilidade natural. Este formando não apenas estava familiarizado com a graciosidade, o requinte, a sofisticação e a coordenação harmónica dos movimentos e gestos corporais exigidos, como possuía ainda um auto-controlo e uma 
auto-disciplina que não tinham paralelo no curso. Estivessem colegas à sua frente, formadores ou um dos próprios Directores de Jogo, ele não tremia, nem vacilava. Danilo, por outro lado, tinha sérias dificuldades técnicas. Possuía uma capacidade de cálculo impressionante. A rapidez e precisão com que chegava aos resultados era uma espécie de espectáculo a que todos, alunos e formadores, assistíamos com curiosidade. Mas, tecnicamente, soçobrava. Estava em Lisboa apenas temporariamente e, aos fins-de-semana, regressava à zona rural onde residia. Suava abundantemente das mãos e pequenas convulsões percorriam o seu corpo quando se sentia observado. Quando executava a técnica do corte ou do encosto fazia-o com demasiada brusquidão. As fichas embatiam umas contra as outras, num movimento excessivamente ruidoso, ou caíam-lhe desajeitadamente das mãos. Empurrava as fichas com demasiada força e estas saltavam da banca, tombando grosseiramente no chão. Ao lançar a bola na roleta, esta saía disparada com tanto ímpeto que a mesa balançava durante alguns segundos. Numa tarde de formação, Danilo estava a baralhar as cartas numa banca de blackjack. No entanto, em vez de seguir rigorosamente os procedimentos ensinados pelos formadores, ele baralhava as cartas informalmente. Um formador, de sobrolho carregado, aproximou-se e protestou energicamente: "houve lá, isto não é uma taberna, é um casino! Deves pensar que estás a jogar sueca com os teus amigos. Isso é forma de baralhar?”. Ruborizado, Danilo desculpou-se, mas a sua alcunha estava já decidida: o taberneiro. No entanto, algumas semanas depois, "taberneiro" já não era apenas uma alcunha que Danilo aceitara divertidamente, era uma unidade de medida que os formandos utilizavam para classificar a qualidade técnica de cada um. Eu próprio, orgulhoso da minha técnica, era um taberneiro a lançar a bola na roleta. Por incrível que possa parecer, esta era a minha maior dificuldade no curso de pagador de banca e não o cálculo. Em cada cinco lançamentos, a bola saía, pelo menos, duas vezes da roleta. Por vezes, atingia as paredes da sala com estrondo e, em algumas circunstâncias, embatia contra colegas meus. As gargalhadas subiam, então, de tom e os meus colegas questionavam, estupefactos: “então, mas não consegues lançar a bola?”. A bola deve ser pressionada contra o estrado interior do prato giratório e deve ser colocada na segunda falange do dedo médio, sendo suportada pelo polegar. Posteriormente, ao mesmo tempo que retiramos o polegar, o dedo médio deve ser lançado contra a bola. Durante este procedimento, o pulso deve permanecer imóvel. De facto, este gesto, aparentemente simples, era para mim extremamente difícil de executar. Inicialmente, procurando esconder a minha própria dificuldade, lançava a bola de uma forma que, embora incorrecta, apresentava maior eficácia. Colocava a bola entre a primeira falange do dedo médio e o polegar, encostava a bola ao estrado e fazia o movimento de estalar os dedos. A bola saía com efeito, rodopiando sobre si mesma, o que não é suposto acontecer, mas, pelo menos, mantinha-se no estrado. Quando fui avaliado na roleta, no entanto, um dos formadores apercebeu-se, repreendendo-me de imediato. Pediu-me que parasse o exercício e explicou-me novamente o procedimento correcto. As três primeiras vezes, a bola caiu no prato em rotação. A cada lançamento, ficava mais nervoso e o suor começava a prender a bola aos meus dedos, dificultando ainda mais a tarefa. O formador, a cada lançamento, repetia: "outra vez". Por uma vez, o movimento saiu de acordo com o pretendido e, para meu alívio, o formador pareceu satisfeito. Nos dias seguintes, tentei cumprir o procedimento à risca, mas, uma e outra vez, voltava a encontrar as mesmas dificuldades. Desgostoso, voltei à minha técnica anterior e foi com este método que, no final, fui aprovado no curso. 
$\mathrm{O}$ adjectivo taberneiro, como referido anteriormente, foi rapidamente assimilado pelos restantes alunos como a unidade de medida básica através da qual hierarquizavam a sua qualidade técnica e a dos outros. Isto é, o par casino-taberna reunia as diversas performances técnicas dos formandos num sistema de valor hierarquizado. O casino representava a elegância e a "distinção" (Idem 2010) da técnica correcta, do procedimento rigorosamente seguido, da auto-disciplina e do auto-controlo emocional e corporal. A taberna, por sua vez, classificava os gestos, movimentos e acções desajeitados, rudes, bruscos, hesitantes, inseguros e "poluidores" (Douglas 1991). Os formandos assimilavam, desta forma, o "arbitrário cultural da cultura dominante", entendida como a cultura legítima e natural daquele "campo" (Bourdieu 1992). A divisão entre casino e taberna reflectia não apenas a "visão e divisão" (Idem 2018) do mundo social, tal como definidas pelos grupos dominantes na figura delegada do formador, mas as relações de força estabelecidas entre "instâncias pedagógicas" e "arbitrários culturais" concorrenciais (Idem 1992). O casino e a taberna, enquanto "instâncias pedagógicas" e "arbitrários culturais" concorrenciais, ganham a sua respectiva posição na hierarquia do "campo social” onde se inserem através das relações de força objectivas que o pulverizam e da expressão simbólica dessas relações (Ibidem). "O acto de força simbólico [...] só é bemsucedido porque está bem fundado na realidade" (Idem 2018:250). Porque "o natural é o que não põe a questão da sua legitimidade" (Ibidem), este "acto de força simbólico" procura naturalizar o "arbitrário cultural dominante" dissimulando as relações de força que lhe deram origem (Ibidem). Os taberneiros, procurando apropriarem-se do posto, são conduzidos, inconscientemente, à inevitável conclusão: para tal, devem incorporar o "arbitrário cultural dominante" e a sua escala de valor "arbitrária”, consentindo à sua própria dominação e reconhecendo a "ilegitimidade de seu [próprio] arbitrário cultural [...], levando consigo a desvalorização do saber e do saber-fazer que eles efectivamente dominam" (Idem 1992:52). Incorporar uma técnica é "gravar na carne e nos ossos dos agentes" a "ordem das coisas" (Wacquant 2002:79). Neste contexto, o contraste entre o "arbitrário cultural dominante" e o seu próprio "arbitrário cultural", ou seja, o contraste entre o casino e a taberna não lhes aparece como produto de assimetrias sociais, mas como fracassos pessoais. O caso mais claro era o de Daniel. Por um lado, este formando era extraordinariamente dedicado, maduro e responsável. Por outro e tal como Danilo, revelava algumas dificuldades técnicas. O extremo nervosismo que o acometia nas bancas quase o incapacitava. Em momentos de avaliação, pressionado pelo olhar dos formadores e dos colegas, Daniel tremia violentamente na banca. O suor, por sua vez, escorria-lhe pela testa. Enquanto pagava, os seus lábios comprimiam-se e as suas feições retesavam-se. Quando empurrava os pagamentos, as fichas precipitavam-se, invariavelmente, sobre o pano. Nervoso, tentava apanhar as fichas e refazer as stacks, mas os espasmos retardavam a tarefa. Ao fim de algumas semanas de formação, Daniel desistiu do curso. Quando lhe liguei no final do dia, ele afirmou pesaroso: “epá, aquilo não é para mim, eu não consigo". Regressou no dia seguinte, depois de um telefonema persuasivo de um dos formadores do curso, mas manteve as suas dificuldades até ao final. Apesar destas observações, o agente, mais uma vez, apropria-se do posto. Daniel costumava elaborar as suas próprias "hierarquias simbólicas alternativas" (Lamont 2000; Sherman 2007), baseando-se nos critérios dominantes, mas acentuando o que considerava ser mais apropriado. Aceitava as suas debilidades técnicas, mas criticava os alunos que falavam e gracejavam na sala de formação, porque ele, assumindo uma postura séria e profissional, representava, nesse particular, a atitude exigida a um pagador de banca. 
Mas num universo social e laboral tão, eminentemente, masculinizado, como são os casinos portugueses $^{6}$, como conciliar a exigência de elegância nos movimentos e gestos corporais com os valores e práticas da masculinidade hegemónica, assente em valores como a força, a virilidade e a robustez (Willis 1981; Nixon 2009; McDowell 2003; Leidner 1993; Cameron 2000; MacDonald e Merrill 2009)? Noutros contextos laborais, as competências exigidas aos pagadores de banca, assentes na elegância e graciosidade dos movimentos, seria considerada efeminada. Nos casinos, pelo contrário, estas mesmas características são ostentadas como marcas de "distinção", detendo um "capital físico" considerável. Naturalmente, estas competências apenas emergem como símbolos de "distinção" porque adquirem o seu respectivo valor no "campo" específico e relativamente autónomo dos casinos, ou seja, estas competências encontram-se ajustadas, elas próprias, a esse universo material e simbólico. Como afirmava Marcel Mauss (2003:14): “cada técnica, cada conduta, tradicionalmente aprendida e transmitida, funda-se sobre certas sinergias nervosas e musculares que constituem verdadeiros sistemas, solidários de todo um contexto sociológico". O "arbitrário cultural” inculcado, incorporado e apropriado não deixa de ser "necessário" por ser "arbitrário" (Bourdieu 1992). A necessidade de determinado "arbitrário cultural" manifesta-se pela coerência simbólica que ele apresenta em relação ao universo social a que se reporta e no qual se inscreve (Ibidem). Ou seja, a técnica inculcada, incorporada e apropriada pelos formandos do curso de pagador de banca, desenhada em função do espaço físico e simbólico onde ela é deve ser performatizada (o casino) e do público que a deve consumir (a elite ${ }^{7}$, incorpora os valores e as práticas desse "campo" e desse público. A força de trabalho, as suas skills e a sua performance laboral devem corresponder ao casino e ao seu público. De facto, só conseguimos compreender a associação entre a elegância da técnica e a óbvia masculinização da força de trabalho dos casinos através de uma análise "interseccional" (Casaca 2012; MacDonald e Merrill 2009) entre género e classe. A potencial contradição entre técnica e masculinidade é resolvida, nos casinos, pela "intersecção" da categoria de classe. A masculinidade exigida aos formandos não é, como tal, uma masculinidade estereotipada como operária ou proletária, mas uma masculinidade sofisticada e requintada, desenhada em função do espaço e do público para o qual deve ser performatizada. Esta "intersecção" entre género e classe, que explica como a elegância e a graciosidade da técnica encontra legitimação no "campo social" dos casinos e como a ele se encontra ajustada, revela toda a sua pertinência na inculcação, incorporação e apropriação da atitude correcta.

\section{"O que interessa é a vossa atitude"}

Ao fim de duas semanas de formação, os alunos foram divididos em três grupos claramente hierarquizados de acordo com as avaliações dos formadores. O primeiro grupo, composto por apenas quatro candidatos, caracterizava-se menos pela sua excelência técnica e mais pelo ambiente de aprendizagem que performatizava. Constituído por uma mulher e três homens, era um grupo bastante silencioso, sério

6 As primeiras mulheres a integrar a categoria profissional de pagador de banca em Portugal foram recrutadas apenas em 1989 para o Casino do Estoril (Estoril-Sol 2007). Um casino a norte do país emprega apenas uma mulher pagadora de banca numa força de trabalho de cerca de 100 profissionais.

7 O Decreto-lei no 41562 de 18 de Março de 1958 estipulava que as "mulheres casadas" e os "assalariados" não poderiam entrar nas salas de jogo dos casinos. 
e formal. Raramente participavam nas conversas dos outros grupos, falavam entre si em murmúrios e só muito esporadicamente soltavam gargalhadas altissonantes. Xavier e Martim pertenciam a este grupo. O primeiro, antigo dançarino de salão, raramente falava com os colegas, dentro e fora do curso, e o segundo, mais extrovertido, costumava repreender os colegas quando os ânimos se exaltavam: "olhem aí, estamos aqui para trabalhar". Danilo, sem sombra de dúvidas, o melhor candidato nos exercícios de cálculo mental, encontrava-se no segundo grupo. Tavares, um dos melhores alunos em termos técnicos, encontrava-se, igualmente, neste grupo intermédio. No entanto, Danilo tinha algumas dificuldades técnicas e Tavares costumava assumir uma postura trocista e estrepitosa. Ele não conseguia fazer um pagamento, lançar uma bola ou distribuir uma carta sem um comentário jocoso ou um gracejo divertido. À medida que o curso avançava, Tavares mostrava-se crescentemente preocupado. Nas suas palavras: “tenho medo que os gajos pensem que eu não sou sério porque às vezes estou na galhofa”. De facto, os alunos do segundo grupo eram constantemente repreendidos por estes momentos esporádicos de socialização e divertimento. Um dos formadores afirmava com frequência:

Levem isto a sério, eu não vou contratar um pagador que eu sei que uma semana depois já está na galhofa com os colegas e com os clientes lá em baixo. Esta sala tem que estar em silêncio absoluto, para vocês se concentrarem. Isto não é difícil, mas exige concentração, não quero palhaçadas na banca.

Os momentos de socialização eram, portanto, constantemente reprimidos e, como podemos observar, existia uma clara preponderância atribuída às competências sociais, ou soft skills. Mais do que o cálculo ou a componente técnica, era a atitude que estruturava a hierarquização dos formandos. Jeffrey Sallaz (2009), trabalhando como dealer em Las Vegas, já havia observado que a componente técnica era constantemente subestimada pelos gestores dos casinos. Estes indivíduos focavam, sobretudo, na "personalidade" dos candidatos, procurando "people’s people”, isto é, pessoas sociáveis e capazes de estabelecer relacionamentos interpessoais com relativa facilidade (Ibidem). Os formadores em Portugal também insistiam: "não se preocupem com as skills, isso vem com o tempo, o que interessa é a vossa atitude. A atitude não pode ser treinada, tem que vir de vocês". No entanto, em Portugal, a atitude exigida aos formandos é manifestamente distinta daquela que Sallaz (2009) observou em relação aos casinos de Las Vegas.

Numa tarde de formação, Neto, um candidato com enormes dificuldades técnicas e de cálculo, estava a fazer de pagador na roleta. Enquanto calculava o resultado, olhava para cima, balançava as pernas e gesticulava. Ao mesmo tempo, ia pronunciando em voz alta: "ora... 17+35, ora isto dá $52.52+16$, ora... 68”. De seguida, fitava os colegas à sua frente, aguardando o seu aval. Então, um dos formadores aproximava-se exaltado e repreendia-o: "queres saber as horas [ora] é isso? Não há cá conversa. Pensas, chegas ao resultado e pagas. Não falas, não dizes ora e não esperas que os teus colegas confirmem se está certo. Isso é forma de estar numa banca? Leva as coisas a sério". Alguns dias mais tarde, Neto já não pronunciava as contas em voz alta, mas continuava a olhar para cima e a mexer os lábios enquanto calculava o resultado. $\mathrm{O}$ formador voltou a interrompê-lo. Nitidamente insatisfeito, convocou a turma completa. Tal como solicitado, os alunos reuniram-se em torno da roleta. De seguida, o formador deu início à repreensão: "é por isto que não queremos que utilizem o cálculo. O vosso colega está aqui a mexer os lábios enquanto faz as contas. Não é bom vocês estarem na banca a olhar para cima e a murmurarem 
as contas, ou a mexerem a boca enquanto calculam o valor". O formador, comicamente, ilustrou a sua argumentação: levantou os olhos para o tecto, perscrutando o horizonte. Ao mesmo tempo, mexia os lábios enquanto balançava ligeiramente a cabeça. Exagerando, a sua mão acariciava, lentamente, o queixo. Os formandos riram em conjunto. Como podemos observar, a atitude subordinava o cálculo. Sempre que o cálculo prejudicava a atitude, os formandos eram repreendidos. Portanto, o perigo da utilização extensiva do cálculo não era apenas um problema de precisão, mas os seus efeitos sobre a atitude do pagador. Os truques e os atalhos serviam, não apenas para auxiliar a tarefa do cálculo, mas para auxiliar a performance de uma determinada atitude. O pagador deve olhar para as fichas no pano e saber, de imediato, o resultado. Tal como a técnica, o cálculo deve ser natural e fluido. $\mathrm{O}$ trabalho e o esforço não devem ser evidentes, ou seja, o trabalho deve ser afastado do trabalho. Dissimular o cálculo é, portanto, fundamental para a performance da atitude correcta.

Se o cálculo deve ser obliterado para facilitar a performance da atitude correcta, a técnica, por sua vez, deve ser desenvolvida para lhe corresponder. De facto, é inevitável estabelecer a associação entre técnica e atitude. Como referido anteriormente, a técnica não é apenas uma mera activação de disposições corporais, mas, igualmente, mentais. Assim, a graciosidade, fluidez e elegância dos movimentos não podem ser dissociadas da exibição de uma atitude confiante, segura e assertiva. Tremer na banca, não apenas compromete a execução da técnica correcta, como, segundo um dos formadores, "mostra incerteza e insegurança, mostra que não estão confiantes na banca e que não estão seguros do que estão a fazer". O contrário também é verdade. A exibição da atitude correcta depende, em grande medida, da execução da técnica correcta. Não podemos assumir uma atitude confiante, segura e assertiva se a nossa qualidade técnica desmente a pertença e o ajustamento ao posto. Técnica e atitude encontram-se, portanto, intimamente associadas. Como tal, a atitude nos casinos portugueses não é uma mera "personalidade" (Ibidem). Técnica e atitude são duas faces da mesma moeda. A técnica está na atitude e a atitude na técnica. Se a técnica pressupõe e exige o controlo emocional, a atitude pressupõe e exige o controlo técnico. Não é possível a performance da atitude correcta sem a performance da técnica correcta e vice-versa. Se, num primeiro momento, assinalei que a técnica é todo um conjunto de disposições físicas e emocionais, todo um "habitus" profissional que garante a "compreensão mútua" (Monteiro 2014:25) entre pagador e casino, todo um esquema de interpretação, representação e acção apropriado a esse "campo social”, todo um saber ser e saber estar, tal acontece apenas porque a técnica implica já o seu complemento necessário: a atitude. Técnica e atitude, ajustadas ao espaço objectivo dos casinos e ao seu público, formam um todo coerente que nada mais é do que o "habitus" profissional dos pagadores de banca. Se a técnica e a atitude nos casinos se ajustam simbólica e materialmente e se ambas se ajustam, simbólica e materialmente, ao espaço objectivo dos casinos e ao seu público, tal significa que a atitude nos casinos, tal como a técnica, foi desenhada em função de valores e práticas masculinas. Mas, mais uma vez, trata-se de uma masculinidade apenas compreensível a partir do elemento de classe e vice-versa. Mas que atitude é esta?

Logo no início do curso, os formadores disponibilizaram um "Manual do Croupier" aos alunos. Segundo o manual: " $50 \%$ do nosso trabalho baseia-se na formação de estudantes e isto é o aspecto técnico, mas os restantes $50 \%$ baseiam-se na educação profissional (a maneira de se comportar nos casinos não é a mesma que noutras empresas)". Mais à frente, o manual referia: 
A educação e a cortesia são indispensáveis: o croupier deve [...] acolher com gentileza todos os clientes que se acercam da mesa de jogo e deve estabelecer imediatamente contacto visual. O croupier deve sempre falar e utilizar uma linguagem adequada: deve ter uma postura correcta [...].É indispensável manter a tranquilidade e serenidade nas situações de tensão e controlar toda a mesa de jogo.

No decorrer do curso, estas prescrições assumiram formas concretas. No decorrer de uma tarde de formação, os candidatos, dispersos pelas várias bancas de jogo, executavam alguns exercícios básicos. Sentado numa cadeira elevada, junto a uma roleta, um dos formadores observava Danilo. Em cima do pano verde estava um telemóvel que servia, temporariamente, de cronómetro. Danilo deveria executar, correctamente e no menor tempo possível, cinco pagamentos diferentes. Deveria expor as fichas no pano e, de seguida, empurrá-las para o cliente imaginário no outro lado da banca. Danilo, de semblante carregado, não levantava os olhos do pano. A determinada altura, o formador voltou-se para a restante turma: "cheguem todos aqui". Em silêncio, terminámos os exercícios e aglomerámo-nos em torno da roleta. Danilo sentia-se claramente desconfortável devido ao inesperado protagonismo. O suor escorria-lhe pela testa e as mãos tremiam-lhe convulsivamente. Uma colega do curso, com a melhor das intenções, aconselhou-o: "não tremas". Ele levantou os olhos por uns instantes, olhou para a colega e protestou sarcasticamente: "obrigado, agora estou mais calmo". Como tremia intensamente, cortava o número errado de fichas. Quando se apercebia do erro, abanava violentamente a cabeça e protestava em voz alta. Em movimentos hesitantes, empurrava os prémios para o cliente imaginário. No entanto, a meio caminho, os dedos, mal posicionados, desequilibravam as stacks e as fichas caiam no pano. $\mathrm{O}$ resultado final foi claramente negativo: cinco pagamentos (quatro incorrectos) em oito minutos. $\mathrm{O}$ formador, de braços cruzados, aguardou tranquilamente que Danilo terminasse o exercício. De seguida, questionou: “o que é que correu mal?”. Como ninguém respondeu, continuou:

A atitude estava totalmente errada. As costas estavam tortas, demasiado debruçadas sobre o pano. As costas têm que estar direitas e apenas a cabeça deve estar inclinada sobre o pano. Depois, afasta-se muito da banca. Devemos andar encostados e paralelamente ao estrado. Os dedos também... devem estar correctamente posicionados para que não desposicionem as fichas nas stacks. O braço deve esticar-se para empurrar as fichas, não as costas, as costas mantêm-se direitas. Não deveria estar a tremer, porque mostra insegurança, incerteza, causa má impressão. Muito menos bufar ou mostrar desagrado cada vez que faz alguma coisa corre mal. Vocês são a imagem do casino, não podem estar a tremer. Mais vale estarem a tremer agora connosco do que depois diante dos clientes, é para isso que o curso serve, mas devem tentar ter uma postura mais serena e confiante. Nós só contamos o tempo para vos meter sob pressão, para vermos como vocês trabalham sob pressão, para vermos a vossa atitude na banca. Não é para competirem ou para fazerem rápido, é para fazerem com calma, mas bem.

Algumas semanas depois, o mesmo formador reuniu os alunos em torno de uma banca de baccarat. Para nossa surpresa, começaram a ser chamados alguns alunos para servir de exemplo à restante turma. O primeiro foi um aluno do primeiro grupo. Segundo as indicações do formador, o candidato deveria executar, com as duas mãos, as técnicas do corte e do encosto. $\mathrm{O}$ aluno, apesar de se encontrar no primeiro grupo, sentiu algumas dificuldades. As mãos tremiam-lhe, dobrava as costas e flectia as pernas, debruçando-se desajeitadamente sobre o pano. Inclinava a cabeça em diagonal para contar o número de 
fichas cortadas. Os seus movimentos eram hesitantes e ruidosos. Por fim, suspirava profunda e sonoramente quando cometia um erro. Quando terminou o exercício, o formador não fez qualquer comentário e o candidato afastou-se pesaroso. De seguida, o formador pronunciou o nome de Xavier. Este aproximou-se calmamente do pano e colocou-se em posição: pernas esticadas e ligeiramente afastadas, costas direitas e cabeça inclinada sobre o pano. O formador deu o sinal de partida e Xavier, tranquilo, executou o exercício na perfeição. As suas mãos não vacilavam, exibindo um controlo emocional invejável. A fluidez e naturalidade da sua técnica eram impressionantes. As fichas pareciam fazer parte do seu corpo e da sua mão, obedecendo voluntariamente à sua vontade. Os seus movimentos eram silenciosos e se estava nervoso, não o demonstrava, apresentando um semblante calmo e sereno. Quando cortou quatro fichas, em vez de cinco, não inclinou a cabeça em diagonal para verificar o número de fichas sobre o pano. Percebeu o erro, observando de cima. O seu rosto permaneceu imóvel e plácido. Recolheu o monte de quatro fichas e voltou a cortar. Desta vez, cortou o número correcto de fichas. Repetiu o exercício com a mão esquerda e fê-lo com idêntica destreza e celeridade. No fim do exercício, o formador comentou as duas performances, elogiando profusamente o trabalho de Xavier:

Viram como ele [Xavier] mexeu nas fichas? Ouviram as fichas a bater umas nas outras? Não fizeram barulho nenhum. Alguns de vocês fazem demasiado barulho com as fichas. É preciso ter alguma elegância. E a postura? Costas direitas, cabeça inclinada, mão esquerda em cima do pano para apoio, pernas ligeiramente afastadas. Ele vê se está a cortar quatro ou cinco fichas cá de cima, não precisa de baixar a cabeça para contar quantas fichas está a cortar, como alguns de vocês fazem. Nós não contamos as fichas que vamos cortar, temos que saber quantas fichas cortamos pela sensibilidade dos dedos e depois confirmamos sem contar e sem baixar a cabeça, vemos cá de cima. Viram como ele reagiu ao erro? Ele falhou um encosto mas não bufou como o vosso colega fez há pouco. Não alterou a sua expressão, nem a sua postura, pegou na ficha caída e continuou o exercício, não se deixou afectar. Viram a atitude? Ele não tremeu, estão aqui todos a olhar para ele, mas ele não quer saber, faz o seu exercício e continua como se nada fosse, com calma, com segurança e confiança.

Como podemos observar, a atitude e a técnica confundem-se e implicam-se de tal forma que, a determinada altura, não conseguimos distingui-las. Os discursos dos formadores fazem referência, não a uma técnica ou atitude isoladas, mas a todo um "habitus" profissional. Não apontam no sentido de uma "actuação de superfície", mas de uma "actuação profunda" (Hochschild 2003). Mas também observamos, nesses discursos, as principais características da atitude exigida aos aspirantes a pagador: segurança, confiança, assertividade, formalidade e elegância. Esta atitude é, manifestamente, distinta daquela que é requerida noutros sectores de actividade.

O sector dos serviços, em expansão desde 1960, transformou significativamente o universo laboral, nomeadamente, o perfil exigido à força de trabalho (Casaca 2012; Matos 2015). Actualmente, as empresas, procurando garantir vantagens competitivas no mercado, atribuem uma importância crescente à "relação de serviço" entre trabalhador e cliente (Ibidem). Como tal, as competências sociais (soft skills) - o relacionamento interpessoal, a amabilidade, a simpatia e a boa apresentação ganham relevância em detrimento das competências técnicas (hard skills) (Ibidem; Hochschild 2003; MacDonald e Sirianni 1996; MacDonald e Korczynski 2009). A "nova morfologia do trabalho" 
(Antunes 2013), na era da "acumulação flexível” (Harvey 1989), é constituída por um "proletariado emocional" (MacDonald e Merrill 2009) que se movimenta num "mercado da personalidade" (Mills 1951). Não devemos, no entanto, exagerar a "imaterialidade" da "relação de serviço" (Pettinger 2004; Witz, Warhurst e Nickson 2003; Warhurst, Thompson e Nickson 2009; Casaca 2012). Os ambientes e espaços de consumo, por exemplo, são intensamente estilizados, tematizados e teatralizados, com o objectivo de produzir uma experiência de consumo que corresponda às expectativas do público que se pretende atrair ou reter (Ibidem). Da mesma forma, os trabalhadores e os seus corpos, para além das suas emoções, são parte integrante e "animada" de toda uma "cenografia" e "paisagem organizacional" "inanimadas" (Ibidem). Assim, o trabalho é, simultaneamente, "estético e emocional" (Hochschild 2003; Casaca 2012; MacDonald e Sirianni 1996; MacDonald e Korczynski 2009; Wolkowitz 2006). As empresas, neste contexto, procuram recrutar ou formar os "habitus" certos, isto é, as disposições emocionais e corporais adequadas à imagem e valores corporativos e ao público que pretendem atrair e reter (Ibidem). Os "habitus" certos são, portanto, aqueles que demonstram uma maior proximidade entre "habitus primários" e "habitus secundários". Dadas as competências estéticas e emocionais exigidas aos trabalhadores não surpreende que o crescimento exponencial do sector dos serviços tenha sido acompanhado pela intensa feminização da força de trabalho (Ibidem). Isto porque as competências requeridas a estes trabalhadores assentam, fundamentalmente, em estereótipos associados à feminilidade subordinada, ou seja, derivam de qualidades que as mulheres possuem, supostamente, em estado natural (Ibidem). Por esta razão, o trabalho de serviço tende a ser percebido como incompatível em relação à masculinidade hegemónica (Nixon 2009; McDowell 2003; Leidner 1993; Cameron 2000; MacDonald e Merrill 2009). O sorriso, por exemplo, é conceptualizado não apenas como feminino, mas como um acto de subordinação (Cameron 2000). Se a masculinidade operária valoriza elementos como a frontalidade, a autoridade e o auto-controlo, as competências sociais requeridas aos trabalhadores do sector dos serviços, como o sorriso, a amabilidade e a deferência, tendem a expressar subordinação (Ibidem). No entanto, o sector dos serviços não produz exigências uniformes (Sherman 2007; Sallaz 2009). Os casinos, enquanto "regimes de produção de serviços", formulam as suas próprias regras formais e informais de atendimento que derivam, inevitavelmente, de estruturas sociais mais amplas e da própria lógica interna do "campo" (Sallaz 2009). Nos casinos analisados, a atitude exigida é, simultaneamente, masculinizada e privilegiada, fenómeno que apresenta óbvias relações com o universo de isolamento e exclusivismo a que a indústria do jogo foi, historicamente, votada. Os casinos requerem, sem dúvida, elementos tipicamente estereotipados como masculinos, como a autoridade, a confiança e o auto-controlo. Desta forma, rejeitam os serviços considerados efeminados, assentes na deferência, empatia, sociabilidade, simpatia e amabilidade. De facto, os pagadores de banca não são incitados a sorrir, a demonstrar deferência ou a evidenciar a sua subordinação. No entanto, a atitude exigida nos casinos também sinaliza uma certa "distinção" relativamente a outros tipos de masculinidade, ou seja, exige-se um elevado nível de formalidade, seriedade, profissionalismo, respeitabilidade e cordialidade. Tal como observámos em relação à técnica, existe uma preocupação acrescida em ajustar, simbólica e materialmente, a atitude dos pagadores ao espaço objectivo dos casinos e ao público que, idealmente, o frequenta. A elegância na técnica deve espelhar a elegância na atitude e vice-versa. 
Se, por um lado, o curso de pagador, introduzindo o agente ao posto, é um micro "processo civilizacional" (Elias 1990), que procura expurgar os gestos e as emoções "poluidoras" e inculcar as marcas da "distinção" profissional, por outro, a apropriação do posto pelo agente é sempre facilitada pela proximidade entre "habitus primários" e "habitus secundários". Aliás, os formadores, insistindo que a atitude "tem que vir" dos candidatos, admitem, desde logo, a impossibilidade de treinar e formar, completamente, os "habitus" certos. Não é apenas a formação dos "habitus" certos que está em causa no curso de pagador, mas o recrutamento e a selecção desses "habitus". Molda-se e inculca-se, tanto quanto se observa aqueles que mais facilmente moldam e inculcam. Mas assim que posto e agente se ajustam, a técnica e a atitude performatizadas transformam-se em recursos que os trabalhadores manipulam para seu próprio benefício, nomeadamente, para se constituírem como “agentes não subordinados", para reforçarem uma identidade sócio-profissional e para inverterem, simbolicamente, as hierarquias sociais que os subordinam (Sherman 2007; Lamont 2000), soluções que, apesar de tudo, permanecem no âmbito do "consentimento" (Burawoy 1979) e não da emancipação.

\section{Conclusão}

Este artigo procurou analisar os "habitus" profissionais dos pagadores de banca de casino em Portugal, nomeadamente, os processos de inculcação, incorporação e apropriação da técnica e atitude correctas. A técnica dos pagadores de banca, relegando o cálculo mental para segundo plano, assenta, fundamentalmente, na performance de movimentos e gestos corporais elegantes, fluidos, graciosos e naturais. A atitude exigida aos candidatos, por sua vez, privilegia a formalidade, a seriedade, o profissionalismo e a respeitabilidade. Técnica e atitude correspondem, material e simbolicamente, entre si. Mas ajustam-se, igualmente, ao "campo social" dos casinos e ao público que, idealmente, o frequenta. A força de trabalho dos casinos faz derivar o seu "habitus" profissional, isto é, a sua técnica e atitude, dessa "intersecção" entre masculinidade e privilégio de classe. Naturalmente, o sucesso da inculcação, incorporação e apropriação desse "arbitrário cultural" depende, em grande medida, da proximidade entre "habitus primários" e "habitus secundários". Mas, assim que o agente se ajusta ao posto, técnica e atitude já não são meras imposições, surgem, ao invés, como recursos mobilizados pelos trabalhadores para se constituírem como agentes não subordinados. Porém, investindo-se no curso e no "arbitrário cultural dominante", apropriando-se do posto e criando dignidade na subalternidade, estes trabalhadores contribuem para a reprodução das relações sociais que os subordinam.

\footnotetext{
João Gomes é bolseiro de doutoramento em Antropologia no Instituto Superior de Ciências Sociais e Politicas e Instituto de Ciências Sociais da Universidade de Lisboa. A bolsa é financiada pela Fundação para a Ciência e Tecnologia.
} 


\section{REFERÊNCIAS BIBLIOGRÁFICAS}

ANTUNES, Ricardo. 2013. Os Sentidos do Trabalho - Ensaio Sobre a Afirmação e a Negação do Trabalho. Coimbra: Almedina.

BARNES, H. Lee. 2002. Dummy up and deal: inside the culture of casino dealing. Reno e Las Vegas: University of Nevada Press.

BOURDIEU, Pierre. 1992 [1970]. A Reprodução: elementos para uma teoria do sistema de ensino. Rio de Janeiro: Francisco Alves Editora.

BOURDIEU, Pierre. 2010 [1979]. A Distinção - Uma Critica Social da Faculdade de Juizo. Lisboa: Edições 70 .

BOURDIEU, Pierre. 2018 [1989]. O Poder Simbólico. Lisboa: Edições 70.

BURAWOY, Michael. 1979. Manufacturing consent: Changes in the labor process under monopoly capitalism. Chicago: University of Chicago Press.

CAMERON, Deborah. 2000. "Styling the worker: Gender and the commodification of language in the globalized service economy". Journal of sociolinguistics 4(3): 323-347.

CASACA, Sara Falcão. 2012. Trabalho Emocional e Trabalho Estético na Economia dos Serviços.

Coimbra: Almedina.

CLASTRES, Pierre. 2003 [1974]. A sociedade contra o Estado. São Paulo: Cosac \& Nayfy.

CRESPO, Jorge. 1981. “Os jogos de fortuna ou azar em Lisboa, em fins do Antigo Regime”. Revista de História Económica e Social 8: 77-94.

CRESPO, Jorge. 2012. O espirito do jogo, estudos e ensaios. Lisboa: Edições Colibri.

DECRETO-LEI No 14643 de 3 de Dezembro de 1927 do Ministério do Interior. Diário do Govêrno nº 267/1927, série I.

DECRETO-LEI No 41562 de 18 de Março de 1958 do Ministério do Interior - Secretaria-Geral. Diário do Governo n. ${ }^{\circ} 56 / 1958$, série I.

DEUS, José Pereira e António Jorge Lé. 2016. Fortuna ou Azar: Dupla Improvável. Figueira da Foz: Rainho e Neves Lda.

DEUS, José Pereira, e António Jorge Lé. 2017. Jogos de Fortuna ou Azar: evocando a primeira lei do jogo em Portugal, 9 décadas de apostas legais. Figueira da Foz: Sociedade Figueira Praia.

DOUGLAS, Mary. 1991 [1966]. Pureza e Perigo - Ensaio sobre a Noção de Poluição e Tabu. Lisboa: Edições 70 .

ELIAS, Norbert. 1990 [1939]. O processo civilizador: uma história dos costumes. Volume I. Rio de Janeiro: Jorge Zahar Editores.

ELIAS, Norbert. 1994 [1987]. A sociedade dos individuos. Rio de Janeiro: Jorge Zahar Editores.

ESTORIL-SOL. 2007. Uma História - 50 anos Estoril-Sol (1958-2008). Estoril: Estoril-Sol.

FOUCAULT, Michel. 1999 [1975]. Vigiar e Punir. Petrópolis: Editora Vozes.

GOMES, João. (no prelo). “O movimento sindical nos casinos: a Associação de Classe e o Sindicato Nacional". Ler História.

HOCHSCHILD, Arlie Russell. 2003 [1979]. The Managed Hearth: commercialization of human feeling. Califórnia: University of Califórnia Press. 
HARVEY, David. 1989. The Condition of Postmodernity. Oxford: Basil Blackwell.

LAMONT, Michèle. 2000. The Dignity of Working Men. Nova Iorque: Russell Sage.

LEFEBVRE, Henri. 2011 [1968]. O direito à cidade. São Paulo: Centauro Editora.

LEIDNER, Robin. 1993. Fast food, fast talk. Berkeley: University of California Press.

MACDONALD, Cameron Lynne e Carmen Sirianni. 1996. Working in the service society. Filadélfia: Temple University Press.

MACDONALD, Cameron Lynne e Marek Korczynski (eds.). 2009. Service work: critical perspectives. Nova Iorque e Londres: Routledge.

MACDONALD, Cameron Lynne e David Merrill. 2009. "Intersectionality in the emotional proletariat: a new lens on employment discrimination in service work". In: Service work: critical perspectives, ed. C. L. MacDonald \& M. Korczynski. Nova Iorque e Londres: Routledge.

MATOS, José Nuno. 2015. O Operário em Construção: do empregado ao precário. Lisboa: Deriva.

MAUSS, Marcel. 2003 [1950]. Sociologia e Antropologia. São Paulo: Cosac Naify.

MCDOWELL, Linda. 2003. Redundant Masculinities. Oxford: Blackwell.

MILLS, Charles Wright. 1951. White Collar. Nova Iorque: Oxford University Press.

MÓNICA, Maria Filomena. 1986. Artesãos e Operários - Indústria, Capitalismo e Classe Operária em

Portugal, 1870-1934. Lisboa: Edições de Ciências Sociais da Universidade de Lisboa.

MONTEIRO, Bruno. 2014. Frágil como o mundo: etnografia do quotidiano operário. Porto: Edições

Afrontamento.

NIXON, Darren. 2009. “I can't put a smiley face on: working-class masculinity, emotional labour and service work in the "new economy". Gender, Work and Organization 16(3): 300-322.

PARKIN, Frank. 1979. The marxist theory of class: a bourgeois critique. Londres: Tavistock.

PATRIARCA, Fátima. 1994. "A regulamentação de trabalho nos primeiros anos do regime corporativo”. Análise Social 128(4): 801-839.

PETTINGER, Lynne. 2004. "Brand culture and branded workers: service work and aesthetic labour in fashion retail". Consumption Markets \& Culture 7(2): 165-184.

Regulamento da Escola Profissional do Sindicato Nacional dos Empregados de Banca nos Casinos. 1956 1957. Arquivo Nacional da Torre do Tombo. Código de referência: PT/TT/SAS/003/003/00139.

Cota actual: Serviços de Acção Social, cx. 10, proc. 17.

ROQUE, Vasco. 2011. A Lei do jogo e seus regulamentos: anotada e comentada. Coimbra: Coimbra Editora.

SALLAZ, Jeffrey. 2009. The Labor of Luck: Casino Capitalism in the United States and South Africa.

Califórnia: University of Califórnia Press.

SHERMAN, Rachel. 2007. Class acts: service and inequality in luxury hotels. Berkeley, Los Angeles e Londres: University of California Press.

SHILLING, Chris. 2003. The Body and Social Theory. Londres: Sage Publications.

VAQUINHAS, Irene Maria. 2006. Nome de código 33856: os jogos da fortuna ou azar em Portugal entre a repressão e a tolerância (de finais do século XIX a 1927). Lisboa: Livros Horizonte. 
WACQUANT, Louis. 2002. Corpo e alma: notas etnográficas de um aprendiz de Boxe. Rio de Janeiro: Relume Dumará.

WARHURST, Chris, Paul Thompson e Dennis Nickson. 2009. "Labor process theory: putting the materialism back into the meaning of service work". In: Service work: critical perspectives, ed. C. L. MacDonald \& M. Korczynski. Nova Iorque e Londres: Routledge.

WEBER, Max. 1968 [1922]. Economy and Society. Berkeley: University of California.

WILLIS, Paul. 1981 [1977]. Learning to labor: how working class kids get working class jobs. Nova Iorque: Columbia University Press.

WITZ, Anne, Chris Warhurst e Dennis Nickson. 2003. "The labour of aesthetics and the aesthetics of organization". Organization 10(1): 33-54.

WOLKOWITZ, Carol. 2006. Bodies at Work. Londres: Sage Publications. 


\title{
“ISTO NÃO É UMA TABERNA, É UM CASINO!”: O CURSO DE PAGADOR DE BANCA
}

Resumo: Durante longas décadas, os casinos em Portugal permaneceram universos sociais e laborais hermeticamente fechados. O Estado impôs, desde cedo, o seu isolamento social, procurando, igualmente, restringir o acesso dos jogadores aos seus espaços. Esta selectividade e exclusivismo foram, prontamente, apropriados pelos trabalhadores do sector, ou seja, eles não hesitaram em mobilizar práticas de "oclusão social" que visavam restringir o acesso à categoria profissional de pagador de banca (dealer) croupier), preservar a raridade do seu título e impedir a vulgarização das suas competências profissionais. Este artigo, baseado numa investigação etnográfica, procura analisar as dinâmicas de constituição do "habitus" profissional dos pagadores de banca de casino, nomeadamente, pretende examinar os métodos de inculcação, incorporação e apropriação da técnica e atitude correctas. $\mathrm{O}$ artigo procura demonstrar, igualmente, como essa inculcação, incorporação e apropriação representam, simultaneamente, um ajustamento a todo um universo material e simbólico, isto é, a todo um saber ser e saber estar.

Palavras-chave: Casinos; ensino; pagadores de banca; técnica; atitude.

\section{“THIS IS NOT A TAVERN, IT'S A CASINO”: THE DEALERS COURSE}

\begin{abstract}
Portuguese casinos remained, for many decades, hermetically closed universes. From an early age, the Portuguese State imposed the social isolation and exclusivity of the gambling industry. These factors were readily appropriated by casino workers, that is, they did not hesitate to mobilize practices of "social closure" that aimed at restricting access to the professional category of dealers, preventing the dissemination of their professional skills. This article, based on ethnographic research, seeks to analyze the construction of their professional "habitus". The intention is to examine the methods of inculcation, incorporation, and appropriation of the correct technique and attitude. The article also seeks to demonstrate how this inculcation, incorporation, and appropriation represent, simultaneously, an adjustment to an entire material and symbolic universe.
\end{abstract}

Keywords: Casinos; trainin; dealers/croupiers; skills; attitude.

RECEBIDO: $22 / 04 / 2020$

APROVADO: $01 / 07 / 2020$ 